\title{
Organization of Student Project Based Activities through Individual Learning Routes
}

\author{
https://doi.org/10.3991/ijet.v14i11.10312 \\ Ekaterina Politsinskaya, Vladislav Lizunkov ${ }^{(\varpi)}$ \\ Tomsk Polytechnic University, Yurga, Kemerovo Oblast, Russia \\ vladeslave@rambler.ru \\ Olga Ergunova \\ The Ural State University of Economics, Ekaterinburg, Russia
}

\begin{abstract}
The article deals with the organization of project training within the university education through the construction of individual educational routes. The authors believe that the value orientationsand the motivationsystem are not only interrelated, but also mutually influence each other, which confirms the need to study value orientations when building an individual route. Based on the Milton Rokich questionnaire, the authors identify three groups of students based on their value orientations. The stages of building individual educational routes are also presented.
\end{abstract}

Keywords - Project based method, independent work, individual learning routes, values.

\section{Introduction}

One of the first-priority purposes of education is to teach a person to perform specific tasks: operate a machine tool, drive a car or write in Russian correctly. Therefore, the present-day system of education is not only to provide a person with a certain score of knowledge, but to teach this person how to apply it in practice and perform any useful and needed by contemporary society activities: theoretical, practical, professional, cognitive, mental or physical ones. The issue of awareness and professional competence necessary for representatives of various professions became urgent after market transformations had been started in the country. In market conditions employees need experts who both know and can constructively use their knowledge in profession. It preconditions their success too. This knowledge and skills can be different, for example, correct use of the Russian language grammar necessary for writing letters, familiarity with peculiarities of a technological process, ability to perform complex tasks, which require for obeying strict rules, norms, and laws [1,2].

Learning is a kind of human activities aimed at meeting special needs to change something what a person does and his (her) own personality over the training process. In the process of learning, that is, while performing various tasks, a human evolves, 
upgrades his/her skills, gains and accumulates experience, obtains new knowledge and develops new skills [12].

\section{Subject and Methods of Research}

\subsection{Survey results analysis Individual educational routes as a means of implementing the project method of teaching}

A teaching process at the University involves a cooperative activity of a teaching person (teaching) and a taught one (learning activity). Learning is thought to be specially organized student activity with the purpose to gain experience of previous generations, that is, to acquire the system of general and special knowledge and actions, to master techniques, which support acquirement and use of obtained knowledge, skills and abilities [11]. Over the process of teaching students have to learn specific material, acquire necessary knowledge, and to master techniques of its application. It is the reason for teaching process organization [4].

We think ideas of American philosopher-idealist John Dewey - founder of project based method deserve special consideration. He suggested "to organize teaching through reasonable activities of a student taking into account his/her personal interests and practical requirements for obtaining knowledge relevant for his/her efficient work in future» [6]. This method is of undoubted importance because students are able to master techniques of independent cognition.

E.N. Yastrebtseva considers an educational project as «cooperative learning and cognitional activity of students that has common objectives, coordinated methods, activity techniques, aimed at common results» [14].

N.Yu. Pakhomova emphasizes didactic specifics of a teaching process. She notes a learning project, from the standpoint of a student, is a possibility to do something independently, on one's own or in a group, involving own abilities to the full [7]. On the other hand N.Yu. Pakhomova mentions another positive side of a project «...in view of a teacher, learning project is a didactic means to be trained in projecting, that is in purposeful actions to resolve problems via performing tasks which are results of examining the problem in certain conditions» [7].

Individual learning routes are a form of project based method T.N. Knyaseva sees individual learning route as a specific method of individual training, which helps students fill in the gaps in their knowledge, improve their abilities and skills, and master competences, as well as encourages them for learning [5]. An individual route is a means of individualization and differentiation of teaching and education. Teaching individualization and differentiation support overcoming contradictions between levels of learning activity set in educational programs and standards and real abilities of each student. Moreover, they are indispensable conditions for implementation of various teaching tasks. For instance, individualization is defined in the paper by K. Selevko as such a way of training process organization, when methods, procedures and rates of teaching are ascertained according to individual characteristics of students. [10]. 


\subsection{Organization of independent work in high school}

It is an individual learning route of a student that furthers implementation of individualization and differentiation in teaching process.

We consider an individual learning route as a structured program of students' activities in a particular period of training [7].

An individual learning route is made on the base of educational needs, individual academic intelligence, and abilities of a student and requirements of standards for instructional content. When an individual learning route is developed a lecturer has to follow the listed below elements:

- Regular diagnostics of each student

- Educational tasks for each student on the base of diagnostics

- Identification and application of the most efficient means to implement an individual approach to the student

- Analysis and control over obtained results

- Formulation of new educational tasks

Up-to-date University standards are focused on development of cultural and professional competences of a graduate, which support his/her further successful professional and social self-development. However, interests of students and their individual characteristics are not taken into account in the standards. Moreover, independent learning is becoming more important in present-day conditions. As the result, students study a significant amount of material to be learnt without anybody's assistance [9].

We know from experience, that students do not succeed working independently because of the following reasons:

- Independent work of students, organized by different lecturers within their disciplines, sometimes has nothing to do with new educational aims

- Independent work of students can't solve stated problems properly due to its insufficient purposefulness, differentiation, minimal regard for individual characteristics, interests and student needs

- Poor control and self-control are the reasons why students do not carry out many tasks they have to do independently, perform them formally or just copy from available sources of information [13]

\subsection{Project method in building individual educational routes for students}

We suppose project based method is to be used for development of student individual learning routes to improve the efficiency of their independent work.

A lecturer develops an individual learning route together with a student. However, it is the student, who should choose a route of own education. A student is not just an inactive consumer in doing his/her personal learning route. It is a self-controlled process, which provides an opportunity to find necessary resources of information, systematize knowledge and determine an own way of knowledge acquisition. 
Student activities necessary for independent work and pre-conditioned by an individual learning route are listed in Table 1.

Table 1. Student activities necessary for independent work and pre-conditioned by an individual learning route

\begin{tabular}{|c|c|c|}
\hline Parameters to be compared & $\begin{array}{c}\text { Activities of independently work- } \\
\text { ing students in the scope of tradi- } \\
\text { tional education }\end{array}$ & $\begin{array}{l}\text { Activities in the scope of an } \\
\text { individual learning route }\end{array}$ \\
\hline Values & Not considered & A basis for development \\
\hline Motivation & $\begin{array}{l}\text { The level of motivation is insuffi- } \\
\text { cient }\end{array}$ & $\begin{array}{l}\text { The level of motivation is suffi- } \\
\text { cient because external needs are } \\
\text { taken into consideration }\end{array}$ \\
\hline $\begin{array}{l}\text { Determination of aim and tasks of } \\
\text { forthcoming activities }\end{array}$ & The student does not participate in it. & $\begin{array}{l}\text { The student determines them on } \\
\text { his/her own }\end{array}$ \\
\hline Implementation & $\begin{array}{l}\text { The lecturer develops a plan on } \\
\text { his/her own without students' partic- } \\
\text { ipation }\end{array}$ & $\begin{array}{l}\text { The student works independently } \\
\text { with slight assistance of the lec- } \\
\text { turer }\end{array}$ \\
\hline Reflection & $\begin{array}{l}\text { The lecturer makes an assessment } \\
\text { according to pre-set criteria }\end{array}$ & $\begin{array}{l}\text { Self-assessment, self-control over } \\
\text { own activities }\end{array}$ \\
\hline
\end{tabular}

We strongly believe each student needs an individual approach because it is an indispensable condition and prerequisite to develop an all-round man.

The most important factor to be considered in developing individual routes is educational motivation. Motivation is a key factor of successful learning. A possibility to be self-sufficient and initiative in learning is a necessary condition to make the instructional content interesting for students and motivate them to learn.

Analyzing the mechanisms regulating human behavior it is necessary to consider his/her values reflected in base needs or necessities.

A person determines his/her life philosophy on the base of the developed system of human values creates a vision of the future, and forms outlooks of further personal development. Therefore, values influence both on present-day and future state of a personality.

As the consequence, values get characteristics of real motives conditioning development and perfection of a personality over the process of consequent selfdevelopment. That is, values are mechanisms of personal growth and selfdevelopment, have an evolving character and are seen as a dynamic system [12].

\section{Survey Results Analysis}

\subsection{Value orientations in building individual educational routes}

Learning activity is of undoubted importance for forming the system of individual values. The influence of educational institutions on development of personal values is determined both by specifics of educational process organization and mutual relations with lecturers and counterparts. The main aim of higher professional education is familiarization with future profession. As the consequence, the quality of an educational 
process can and is to be improved via formation of professional competences and on the base of values relevant for the future profession.

Values encourage a person to cognize the social world and at the same time they perform mental regulation of human behavior in the society. As the result, values and the system of motivational entities are not only interrelated but interdependent, so it is necessary to know values for development of an individual learning route. Therefore, individual motivational values of students are to be taken into consideration.

Questionnaires and various checklists are the most wide-spread methods to learn values of students. Some information can be obtained in the course of object-oriented conversations during seminars, observations and from purposefully selected tasks, especially when a student has an opportunity to choose from different tasks. To analyze the values of students we propose to use a well-known checklist by Milton Rokeach [5].

Three student groups with similar values can be singled out according to the results of questionnaires (Table 2).

Table 2. Student groups according to the results of diagnostics

Groups formed according to the results of diagnostics

Group I: Entertainment, love; freedom of action, happy family life, close and good friends.

Group II: Interesting job, financial security, cognition, health, active and busy life.

Group III: Interesting job, financial security, health, creativity, beauty of nature and art.

Individual learning routes were developed for each singled out group on the base of diagnostics results.

Group I: As a rule, these are students who chose their future profession thoughtlessly and are disinterested in getting education. Their decision was determined by parents' will, convenience. Love, entertainment, and friends were among the dominating values at the beginning of education. For the students of this group one has to develop more specific and practice-oriented tasks. The progress of these students is possible only through constant addressing to the learnt before material and revision of new material, as well as by means of a great amount of exercises for review the learnt material.

Group II: Students of this group are interested in learning, they are cognitively active. The analysis of values revealed the first rank of creativity. Students get tasks for creative independent work. These tasks can go beyond the scope of discipline to be studied. As a rule, it is related to research work, writing scientific papers, taking part in scientific conferences with reports, working in seminars, participating in various contests and forums. This activity encourages students to follow their personal interests, promotes motivation for learning this discipline, as well for future profession.

Group III: Students of the third group are eager to have an interesting job, earn their living in future, and enjoy public recognition. They have keen interest for the subjects they study, deep knowledge, stable activity and learning self-sufficiency. An individual route is to involve students constantly into learning additional material, and make them have complex tasks or those ones requiring for an original decision [5]. 


\subsection{Stages of building an individual educational route}

Each individual learning route is a structured program of student's actions at a certain stage of education. Development of an individual learning route includes several phases:

Phase 1. Analysis and diagnostics: Investigation into values of students followed by their division into 3 groups.

Phase 2. Development of an individual learning route for each student

- A period of an individual learning route completion is identified, for example, a term.

- A schedule of reports on route completion is worked out.

- A set of tasks is made according to the results of diagnostics.

The tasks for all groups are three-leveled. The first basic level includes tasks all the students have to do in the context of the studied discipline, here practice-oriented tasks and problems are to be used [15]. The second level comprises tasks selected according to the results of student values diagnostics. However, the second group tasks are constructive and the tasks for the third group require for deep knowledge of the discipline.

Phase 3. Correction and control All completed tasks are undergone to checking, analysis and assessment both by the student and lecturer. Mistakes made in the process of project implementation are analyzed. Students work independently to perform the tasks and become proficient in material to be learnt within their powers. Obtained results of completed tasks are graded, and at the end the lecturer gives a comment on each student's rating.

When tasks are carried out a learning route can be corrected together with the lecturer and in dependence on the change in students' values.

Students who implement an individual learning route possess personal qualities a present-day employee needs. These are abilities to control, assess own activities objectively and correct them. These abilities are important for the process of learning too. In the process of purposeful control over student activities it is necessary to check the level of their success, which makes it possible to determine the degree of developed skills and obtained knowledge at a particular stage of learning, and, as the result, to meet the requirements of a standard. An important aspect of the learning process is an ability to correlate self-assessment to the assessment made externally - reflection. If the results of assessment are different, correction of learning results is necessary [12].

\section{Conclusion}

Therefore, organization of project-based activities through individual learning routes will support the development of student professional competences, skills of self-organization and self-control over own learning activity. At present it is important 
because a future specialist becomes a subject of professional activity able to selfdevelop, manage projects and re-organize his/her activities.

\section{Acknowledgement}

These authors would like to thank to National Research Tomsk Polytechnic University for the chance to participate in this useful, scientific and research forum.

\section{Referenses}

[1] N.Arranz, F.Ubierna, M.F.Arroyabe, C.Perez,Fdez. de Arroyabe, J.C. The effect of curricular and extracurricular activities on university students' entrepreneurial intention and competences //Studies in Higher Education- 2017.- Vol.42 2(11). - P. 1979-2008 8 https://doi.org/10.1080/03075079.2015.1130030

[2] G.A.Atanov, Activity approach in education / G.A. Atanov. - Donetsk: «EAI-press», 2001. $-160 \mathrm{p}$.

[3] E.Fleacă, Entrepreneurial curriculum through digital-age learning in higher education - A process-based model // TEM Journal. - 2017. - Vol.6(3). - P. 591-598 https://doi.org/10.18421/TEM63-22.

[4] J.Flodin, The impact of student feedback on teaching in higher education // Assessment and Evaluation in Higher Education. - 2017. - Vol.42 (7). - P. 1054-1068. https://doi.org/10.1080/02602938.2016.1224997.

[5] T.N.Knyaseva, Individual learning route of a child as a condition to implement psychological and educational correction of younger schoolchildren with developmental delay / T.N. Knyaseva // Correctional pedagogic. - 2005. -№1.

[6] N.A.Kralya, Learning project based method as a meant to activate learning activity of students: study guide / N.A. Kralya. - Omsk: OmSU publishing, 2005 - 59p; pp.11-12

[7] M.E.Menon, E.Markadjis, N.Theodoropoulos., M.Socratou, Influences on the intention to enter higher education: the importance of expected returns // Journal of Further and Higher Education/. - 2017. - Vol.41 (6). - P. 831-843.

https://doi.org/10.1080/0309877X.2016.1188897.

[8] Milton Rokeach, Then a true of human values. N.Y., 1973

[9] Pamela A. Maher, Janelle M. Bailey, Allan M. Tucka, Teaching Process Skills to PreEngineers using Situated Learning - A Case Study// International Journal of Engineering Pedagogy (iJEP) Vol 8, No 5 (2018) pp.11-12 https://doi.org/10.3991/ijep.v8i5.9036

[10] G.K. Selevko, Present-day teaching technologies: Study guide / G. K. Selevko. - M.: Public Education, 1998. , p. 92

[11] K.Shimazaki, M.Adachi, M.Nakayama,Effectiveness of instruction for summarising handouts and academic writings // InternationalJournal of Emerging Technologies in Learning Volume 13, Issue 8, 2018, Pages 51-63. https://doi.org/10.3991/ijet.v13i08.8333

[12] N.Sudarwati, Rukminingsih,Evaluating e-learning as a learning media a case of entrepreneurship e-learning using schoology as media //nternationalJournal of Emerging Technologies in Learning Volume 13, Issue 9, 2018, Pages 269-279.

https://doi.org/10.3991/ijet.v13i09.7783

[13] L.Sugandi, Y.Kurniawan,The influence of information technology on the information and service quality for the teaching and learning // International Journal of Emerging Technol- 
ogies in Learning Volume 13, Issue 12, 2018, Pages 230-237. https://oi.org/ $10.3991 /$ ijet.v13i12.8665

[14] E.N. Yastrebtseva, Five evenings. Conversations on telecommunication educational projects / E.N. Yastrebtseva. - M.: «Project Harmony» YUNIPRESS, 1998 - p. 18

[15] N.Yu. Pakhomova, Learning project: its possibilities / N.Yu. Pakhomova // Teacher. 2000, №4. - p. 16

\section{$7 \quad$ Authors}

Ekaterina Politsinskaya, PhD, Department of Digital Technology, ${ }^{1}$ Tomsk Polytechnic University Yurga Institute of Technology,Russia, Katy031983@mail.ru. The area of scientific interests is the theory and methodology of vocational training.

Vladislav Lizunkov, PhD, Department of Digital Technology, Tomsk Polytechnic University Yurga Institute of Technology, Russia, vladeslave@rambler.ru. The area of scientific interests is the theory and methodology of vocational training.

Olga Ergunova, PhD, The Ural State University of Economics, Department of regional and municipal economics and management Ural Federal University named after the first President of Russia B.N.Yeltsin, Department of Integrated Marketing Communications and Branding Yekaterinburg, Russia, forstud@vstu.ru. Area of scientific interests: pedagogy, economy of the region.

Article submitted 2019-02-13. Resubmitted 2019-03-23. Final acceptance 2019-03-24. Final version published as submitted by the authors. 